\title{
Synthesis of a Novel Cyclic Donor-Acceptor Conjugate for Selective Recognition of ATP
}

Prakash P. Neelakandan, Mahesh Hariharan and Danaboyina Ramaiah*

Photosciences and Photonics Division

Regional Research Laboratory (CSIR)

Trivandrum 695 019, INDIA

* To whom correspondence should be addressed at:

Photosciences and Photonics Division

Regional Research Laboratory (CSIR)

Trivandrum 695 019, INDIA.

Tel: +91471 2515362. Fax: +914712490186.

E-mail : $\underline{\text { rama@csrrltrd.ren.nic.ind or d_ramaiah@ rediffmail.com }}$

\section{Supporting Information}

Details of synthesis and calculations and Figures S1 to S10 showing NMR data, changes in absorbance of $\mathbf{1}$ and $\mathbf{2}$ in presence of nucleotides, nucleosides and phosphate anion under different experimental conditions. 
1. General experimental techniques. The equipment and procedure for melting point determination and spectral recordings were described in our earlier publications. ${ }^{1,2}{ }^{1} \mathrm{H}$ and ${ }^{13} \mathrm{C}$ NMR were measured on a $300 \mathrm{MHz}$ Bruker advanced DPX spectrometer. The electronic absorption spectra were recorded on a Shimadzu UV-VIS-NIR spectrophotometer. Fluorescence spectra were recorded on a SPEX-Fluorolog F112X spectrofluorimeter. Quinine sulphate $\left(\Phi_{f}=0.54\right)$ in $0.1 \mathrm{~N} \mathrm{H}_{2} \mathrm{SO}_{4}$ was used as the standard. The quantum yields of fluorescence were calculated using the equation 1 ,

$$
\Phi_{u}=\frac{A_{s} F_{u} n_{u}^{2}}{A_{u} F_{s} n_{s}^{2}} \Phi_{s}
$$

where, $A_{s}$ and $A_{u}$ are the absorbance of standard and unknown, respectively. $F_{s}$ and $F_{u}$ are the areas of fluorescence peaks of the standard and unknown and $n_{s}$ and $n_{u}$ are the refractive indices of the solvents used for the standard and unknown, respectively. $\Phi_{s}$ and $\Phi_{u}$ are the fluorescence quantum yields of the standard and unknown compound. Cyclic voltammograms were recorded in Bioanalytical Systems Inc., BAS-CV50W cyclic voltammeter. Doubly distilled water was used in all the studies. Petroleum ether used was the fraction with boiling range $60-80{ }^{\circ} \mathrm{C}$. All experiments were carried out at room temperature $\left(25 \pm 1{ }^{\circ} \mathrm{C}\right)$, unless otherwise mentioned.

2. Calculation of association constants $\left(\boldsymbol{K}_{\text {ass }}\right)$. Nucleotides, nucleosides and phosphate (Sigma Aldrich) solution were prepared in distilled water. The binding affinities of $\mathbf{1}$ and $\mathbf{2}$ were calculated using Benesi-Hildebrand equation 2,

$$
\frac{1}{\left(A_{f}-A_{o b}\right)}=\frac{1}{\left(A_{f}-A_{f c}\right)}+\frac{1}{K\left(A_{f}-A_{f c}\right)[\text { Ligand }]}
$$

where, $K$ is the equilibrium constant, $A_{f}$ is the absorbance of free host, $A_{o b}$ is the observed absorbance in the presence of various ligands and $A_{f c}$ is the absorbance at saturation. The linear dependence of $1 /\left(A_{f}-A_{o b}\right)$ on the reciprocal of the ligand concentration indicates the formation of a 1:1 molecular complex between ligands and the host. 


\section{Calculation of change in free energy $\left(\Delta G_{E T}\right)$ for photoinduced electron}

transfer. The change in free energy $\left(\Delta G_{E T}\right)$ for the photoinduced electron transfer reaction was evaluated according to Rehm-Weller equation $3,^{3}$

$$
\Delta \mathrm{G}_{\mathrm{ET}}=\mathrm{E}_{\mathrm{ox}}-\mathrm{E}_{\mathrm{red}}-\mathrm{w}_{\mathrm{p}}-\mathrm{E}_{0,0}
$$

where, $E_{(0,0)}$ is the singlet excitation energy in $\mathrm{eV}, w_{p}$ is the work term which was taken as $-0.056 \mathrm{eV}$ in water, ${ }^{4} E_{o x}$ is the oxidation potential of the donor and $E_{\text {red }}$ is the reduction potential of the acceptor. The oxidation potential of anthracene $(1.9 \mathrm{eV})$, reduction potential of viologen $(-0.45 \mathrm{eV})$ and singlet state energy of anthracene $(3.18 \mathrm{eV})$ were used for calculations. ${ }^{5}$ The change in free energy value for the electron transfer from the singlet excited state of anthracene to the viologen was found to be $-0.77 \mathrm{eV}$, which predicts a facile quenching of the anthracene chromophore fluorescence by the viologen moiety through an electron transfer mechanism.

\section{Synthesis of the cyclic system 1 and the model compound 2}

The synthesis of the cyclic derivative 1 was achieved as shown in Scheme 1.

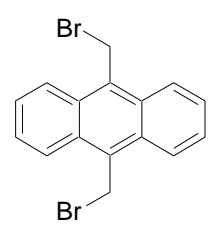

3

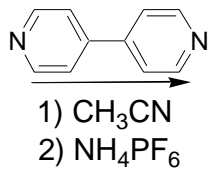

2) $\mathrm{NH}_{4} \mathrm{PF}_{6}$

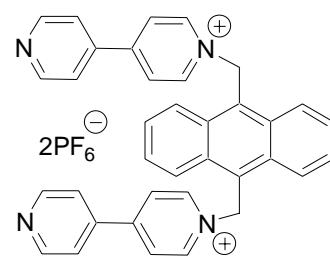

4

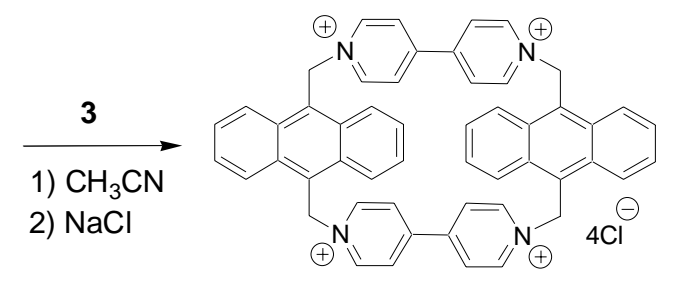

1

\section{Scheme 1}

Note: The numbers of the compounds given here correspond to those given in the manuscript.

Preparation of 1,1'-[9,10-anthrylbis(methylene)]bis-4,4'bipyridinium bis(hexafluorophosphate) (4). A solution of 9,10-bis(bromomethyl)-anthracene (1 g, $2.747 \mathrm{mmol})$ in dry $\mathrm{CH}_{3} \mathrm{CN}(20 \mathrm{~mL})$ was added to a solution of 4,4'-bipyridyl (2.143 $\mathrm{g}$, $13.735 \mathrm{mmol})$ in dry $\mathrm{CH}_{3} \mathrm{CN}(5 \mathrm{~mL})$ over a period of $30 \mathrm{~min}$ at $25{ }^{\circ} \mathrm{C}$. The reaction mixture was refluxed for $4 \mathrm{~h}$ at $80{ }^{\circ} \mathrm{C}$ and then cooled to room temperature. The precipitated product was filtered, washed with dry $\mathrm{CH}_{3} \mathrm{CN}(3 \mathrm{~mL})$ and dissolved in water (25 mL). The aqueous solution was washed with $\mathrm{CH}_{2} \mathrm{Cl}_{2}$ thrice, $5 \mathrm{~mL}$ each time, and then water was removed under vacuum to give a solid residue, which was then recrystallized 
from water. The product was redissolved in hot water, and a saturated aqueous solution of $\mathrm{NH}_{4} \mathrm{PF}_{6}$ was added to yield $1.64 \mathrm{~g}(88 \%)$ of $4, \mathrm{mp}>250{ }^{\circ} \mathrm{C}$, after recrystallization from acetonitrile; ${ }^{1} \mathrm{H}$ NMR $\left(\mathrm{CD}_{3} \mathrm{COCD}_{3}, 300 \mathrm{MHz}\right) \delta 7.40(4 \mathrm{H}, \mathrm{s}), 7.81-7.85(4 \mathrm{H}, \mathrm{m})$, 7.98-8.00 (4H, d, J = 6.1 Hz), 8.59-8.62 (4H, d, J = 6.7 Hz), 8.70-8.74 (4H, m), 8.88$8.90(4 \mathrm{H}, \mathrm{d}, \mathrm{J}=6.1 \mathrm{~Hz}), 9.21-9.23(4 \mathrm{H}, \mathrm{d}, \mathrm{J}=6.7 \mathrm{~Hz}) ;{ }^{13} \mathrm{C} \mathrm{NMR}\left(\mathrm{CD}_{3} \mathrm{COCD}_{3}, 75 \mathrm{MHz}\right)$ $\delta$ 58.2, 114.3, 114.5, 115.8, 116.2, 117.7, 123.8, 127.1, 128.7, 131.2, 144.7; HRMS (FAB) $m / z$ Calcd for $\mathrm{C}_{36} \mathrm{H}_{28} \mathrm{~N}_{4} \mathrm{P}_{2} \mathrm{~F}_{12}\left(\mathrm{M}-\mathrm{PF}_{6}\right)$ : 661.5986. Found: $661.5991\left(\mathrm{M}-\mathrm{PF}_{6}\right)^{+}$.

Preparation of the cyclic derivative 1. A solution of 9,10-bis(bromomethyl)anthracene $(0.3 \mathrm{~g}, 0.8 \mathrm{mmol})$ and $4(1 \mathrm{~g}, 1.2 \mathrm{mmol})$ in dry $\mathrm{CH}_{3} \mathrm{CN}(100 \mathrm{~mL})$ was heated under reflux at $80{ }^{\circ} \mathrm{C}$ for $24 \mathrm{~h}$. The reaction mixture was cooled to room temperature to give a precipitate which was filtered and washed with dry $\mathrm{CH}_{3} \mathrm{CN}(10 \mathrm{~mL})$. The precipitate was redissolved in water, washed with $\mathrm{CH}_{2} \mathrm{Cl}_{2}$ thrice, $3 \mathrm{~mL}$ each time. A saturated aqueous solution of $\mathrm{NaCl}$ was added to the solution to give $26 \%$ of $\mathbf{1}$, after recrystallisation from a mixture $(1: 3)$ water and methanol, $\mathrm{mp}>300{ }^{\circ} \mathrm{C} ;{ }^{1} \mathrm{H} \mathrm{NMR}\left(\mathrm{D}_{2} \mathrm{O}\right.$, $300 \mathrm{MHz}) \delta 7.09(8 \mathrm{H}, \mathrm{s}), 7.81-9.01(32 \mathrm{H}, \mathrm{m}) ;{ }^{13} \mathrm{C} \mathrm{NMR}\left(\mathrm{D}_{2} \mathrm{O}, 75 \mathrm{MHz}\right) \delta 72.9,122.2$, 124.6, 125.3, 127.7, 129.3, 131.3, 142.7; HRMS (FAB) $\mathrm{m} / z$. Calcd for $\mathrm{C}_{52} \mathrm{H}_{40} \mathrm{~N}_{4} \mathrm{Cl}_{4}(\mathrm{M}-$ 2Cl): 791.8064. Found: $791.8072(\mathrm{M}-2 \mathrm{Cl})^{+}$.

Preparation of 1-[(anthr-9-yl)methyl]-1'-butyl-4,4'-bipyridinium dibromide (2). The synthesis of the model system 2 was achieved as shown in Scheme 2.

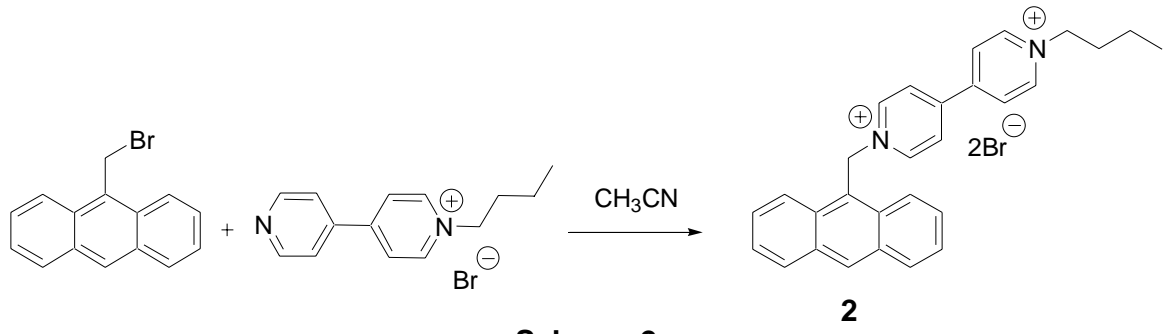

Scheme 2

Note: The numbers of the compounds given here correspond to those given in the manuscript.

To a solution of 9-(bromomethyl)anthracene $(0.16 \mathrm{~g}, 0.6 \mathrm{mmol})$ in dry acetonitrile (50 mL), 1-butyl-4,4'-bipyridinium bromide (0.18 g, $0.6 \mathrm{mmol})$ was added and stirred for $12 \mathrm{~h}$ at $25{ }^{\circ} \mathrm{C}$. Precipitated product was filtered, dried and recrystallized from a mixture (6:4) of methanol and ethyl acetate to give $79 \%$ of 2 , mp $289-290{ }^{\circ} \mathrm{C}$; ${ }^{1} \mathrm{H}$ NMR (300 MHz, DMSO-d $\left.{ }_{6}\right) \delta 0.88(3 \mathrm{H}, \mathrm{t}, \mathrm{J}=7.4 \mathrm{~Hz}), 1.28-1.29(2 \mathrm{H}, \mathrm{m}), 1.89-1.91(2 \mathrm{H}, \mathrm{m}), 4.67$ 
$(2 \mathrm{H}, \mathrm{t}, \mathrm{J}=7.4 \mathrm{~Hz}), 7.08(2 \mathrm{H}, \mathrm{s}), 7.61-9.33(17 \mathrm{H}, \mathrm{m}) ;{ }^{13} \mathrm{C}$ NMR $\left(75 \mathrm{MHz}\right.$, DMSO-d $\left.{ }_{6}\right) \delta$ 13.3, 18.7, 32.7, 56.1, 60.5, 121.6, 123.3, 125.8, 126.7, 126.9, 128.4, 129.6, 131.1, 131.4, 131.5, 144.8, 145.7, 148.6, 149.1. HRMS (FAB) $\mathrm{m} / \mathrm{z}$ Calcd for $\mathrm{C}_{29} \mathrm{H}_{28} \mathrm{~N}_{2} \mathrm{Br}_{2}(\mathrm{M}-\mathrm{Br}$ ): 484.4501. Found: $484.4495(\mathrm{M}-\mathrm{Br})^{+}$.

\section{References}

1. Junjappa, H.; Saxena, M. K.; Ramaiah, D.; Loharay, B. B.; Rath,N. P.; George, M. V. J. Org. Chem. 1998, 63, 9801.

2. Sajimon, M. C.; Ramaiah, D.; Thomas, K. G.; George, M. V. J. Org. Chem. 2001, 66, 3182.

3. (a) D. Rehm and A. Weller, Ber. Bunsenges Phys. Chem. 1969, 73, 834. (b) A. Weller, Z. Phys. Chem. 1982, 133, 93.

4. G. J. Kavarnos, in Fundamentals of Photoinduced Electron Transfer, VCH Publishers, Inc., New York, 1993, p. 39.

5. (a) Bernhardt, P. V.; Flanagan, B. M.; Riley, M. J. J. Chem. Soc., Dalton Trans., 1999, 3579. (b) Joseph, J.; Eldho, N. V.; Ramaiah, D. Chem. Eur. J. 2003, 9, 5926. 


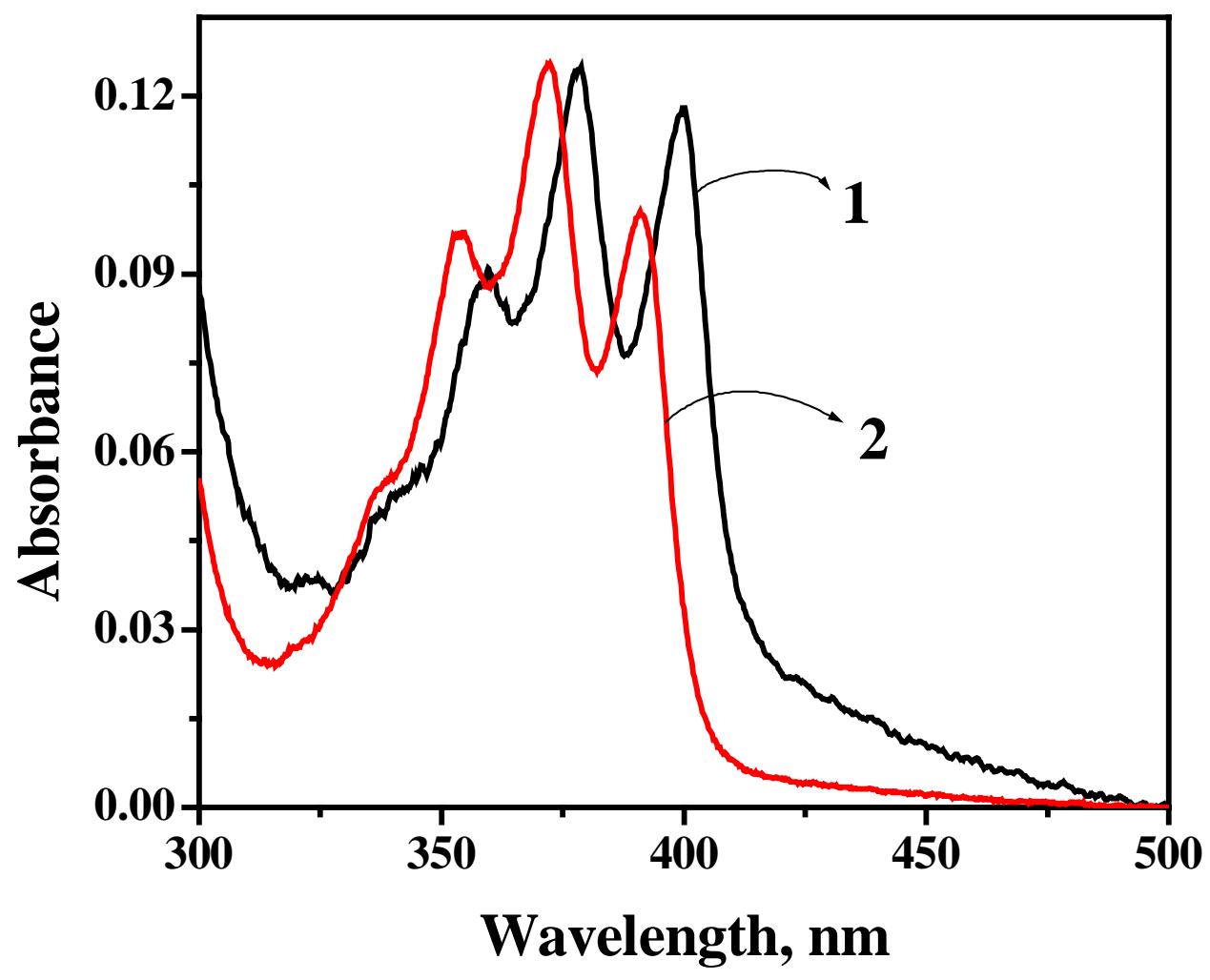

Figure S1. Absorption spectra of the cyclic derivative $1(11 \mu \mathrm{M})$ and the model derivative $2(15 \mu \mathrm{M})$ in $10 \mathrm{mM}$ phosphate buffer (pH 7.4). 


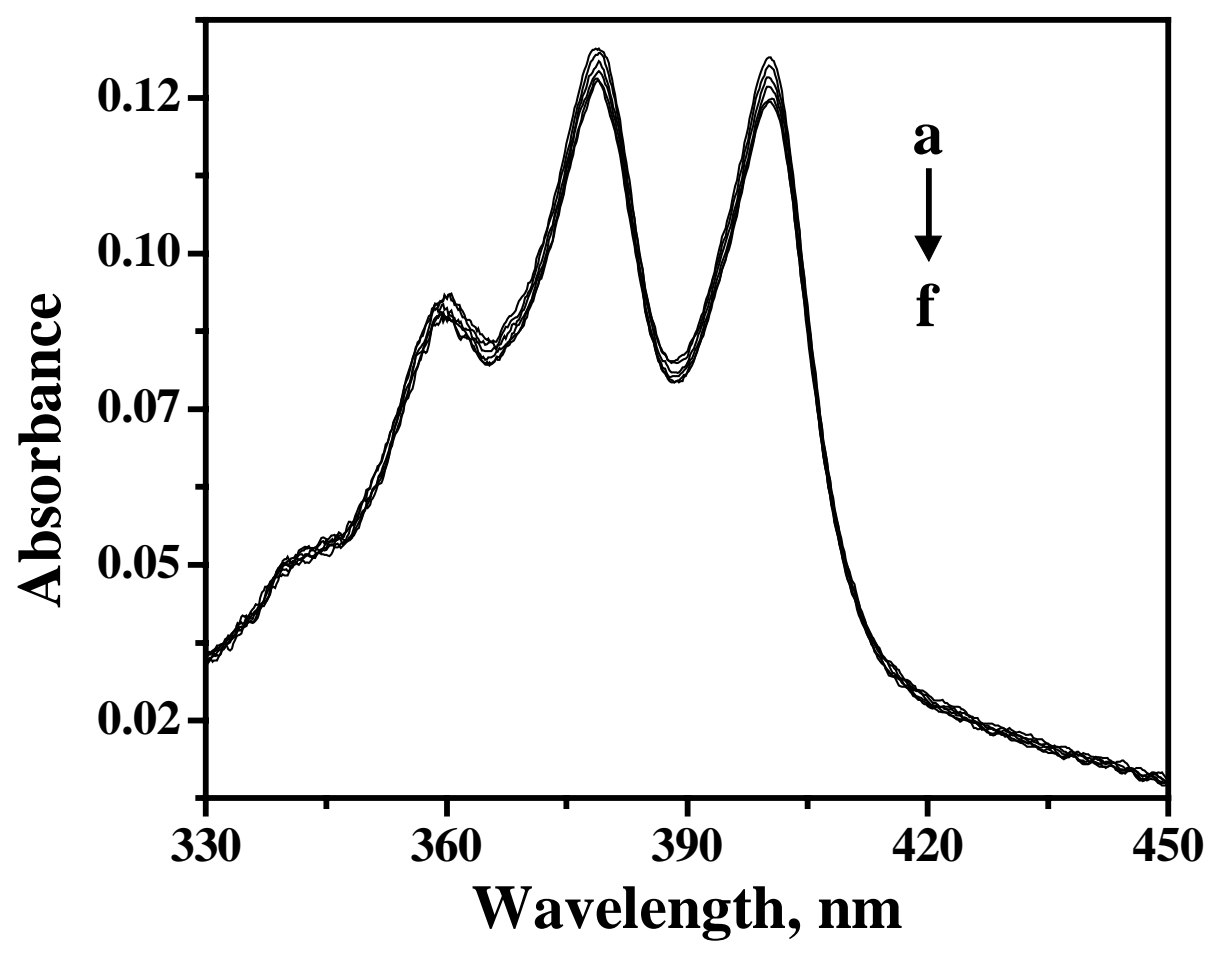

Figure S2. Effect of $\mathrm{Na}_{3} \mathrm{PO}_{4}$ concentration on the absorption spectrum of $\mathbf{1}(11 \mu \mathrm{M})$ in $10 \mathrm{mM}$ phosphate buffer (pH 7.4). $\left[\mathrm{Na}_{3} \mathrm{PO}_{4}\right]$ (a) 0 , (b) 0.17 , (c) 0.25 , (d) 0.33 , (e) 0.42 and (f) $0.50 \mathrm{mM}$. 


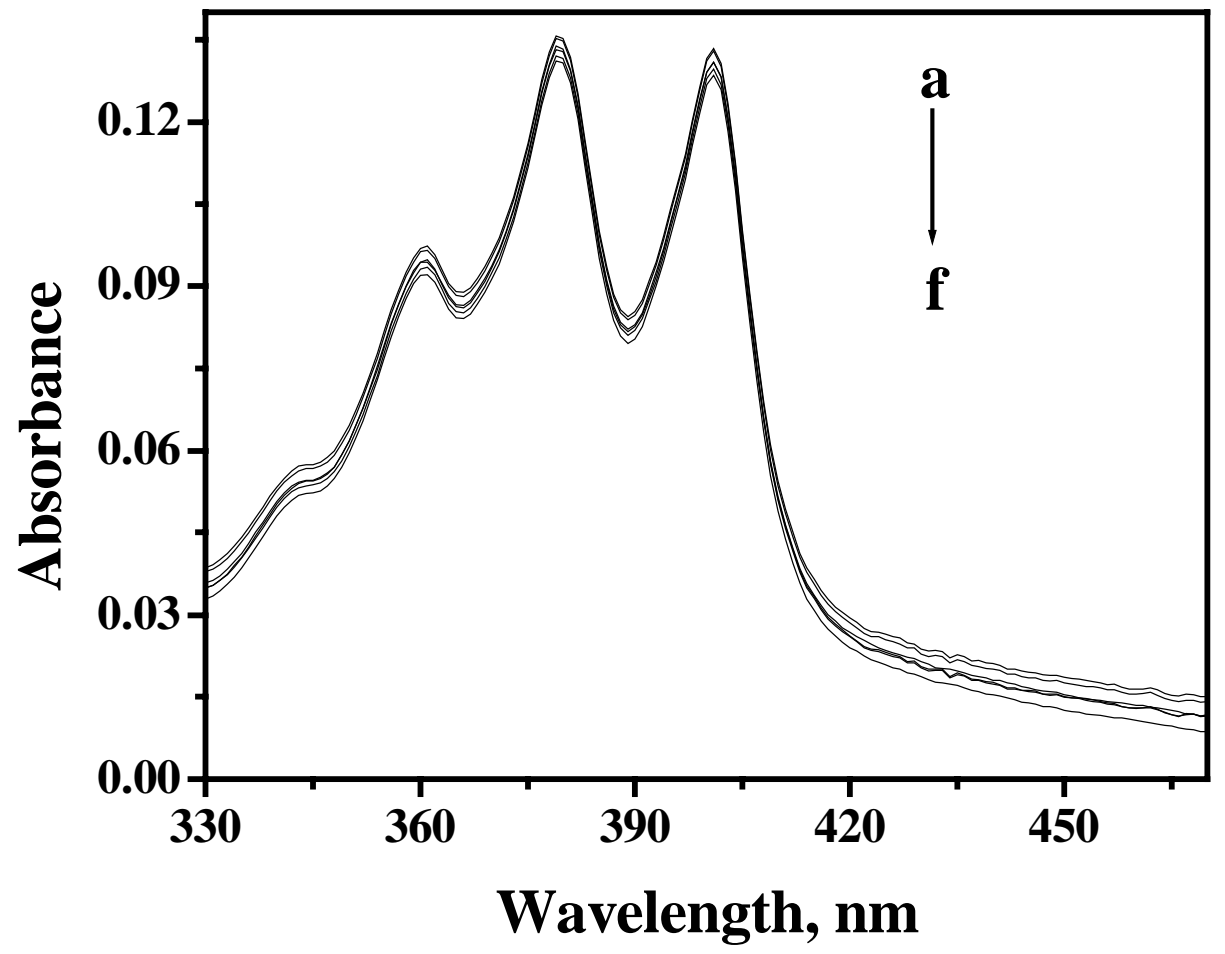

Figure S3. Effect of adenosine concentration on the absorption spectrum of $\mathbf{1}(11 \mu \mathrm{M})$ in $10 \mathrm{mM}$ phosphate buffer (pH 7.4). [Adenosine] (a) 0, (b) 0.17, (c) 0.25, (d) 0.33, (e) 0.42 and (f) $0.50 \mathrm{mM}$. 


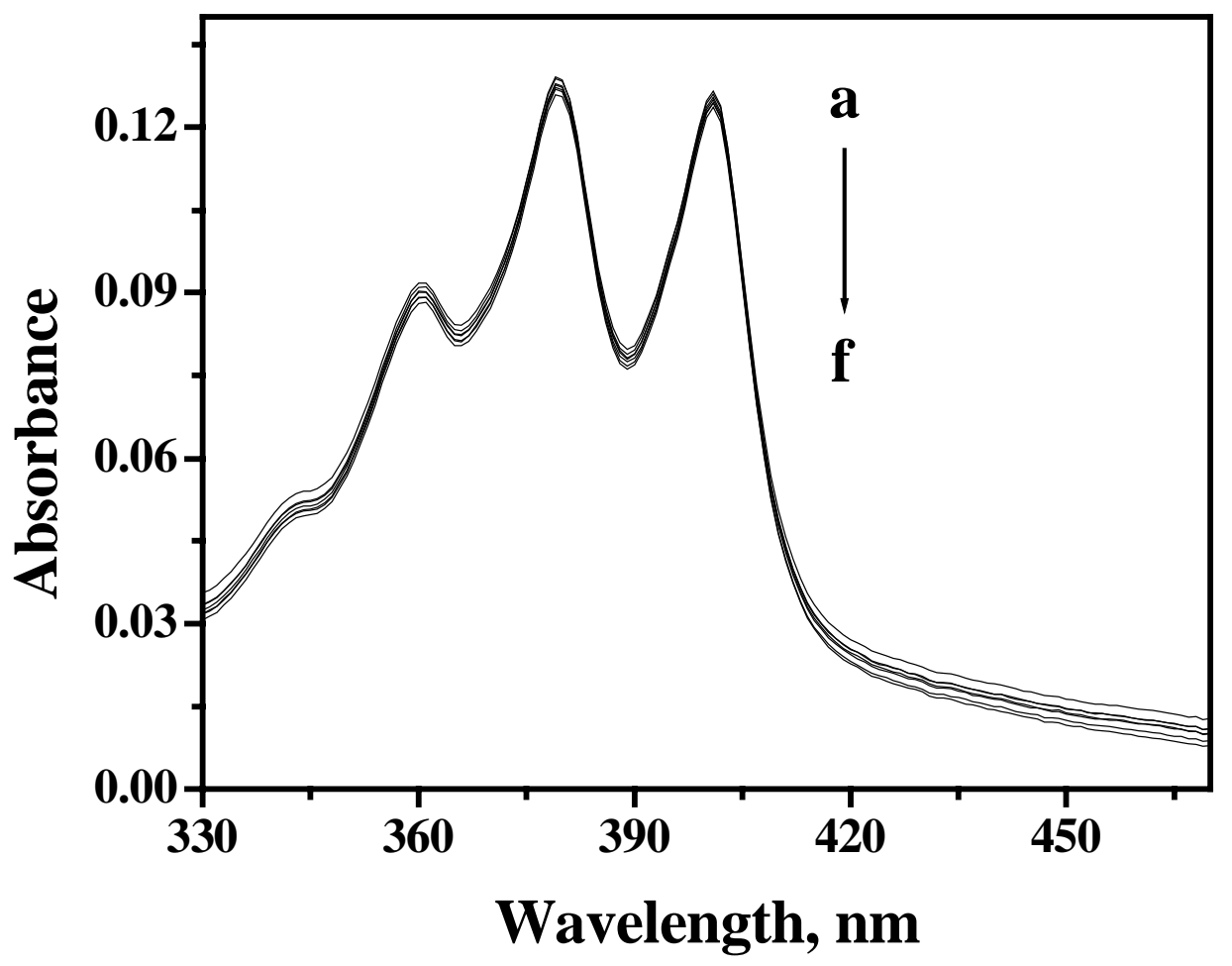

Figure S4. Effect of adenosine-5'-monophosphate (AMP) concentration on the absorption spectrum of $\mathbf{1}(11 \mu \mathrm{M})$ in $10 \mathrm{mM}$ phosphate buffer (pH 7.4). [AMP] (a) 0, (b) 0.17 , (c) 0.25 , (d) 0.33 , (e) 0.42 and (f) $0.50 \mathrm{mM}$. 


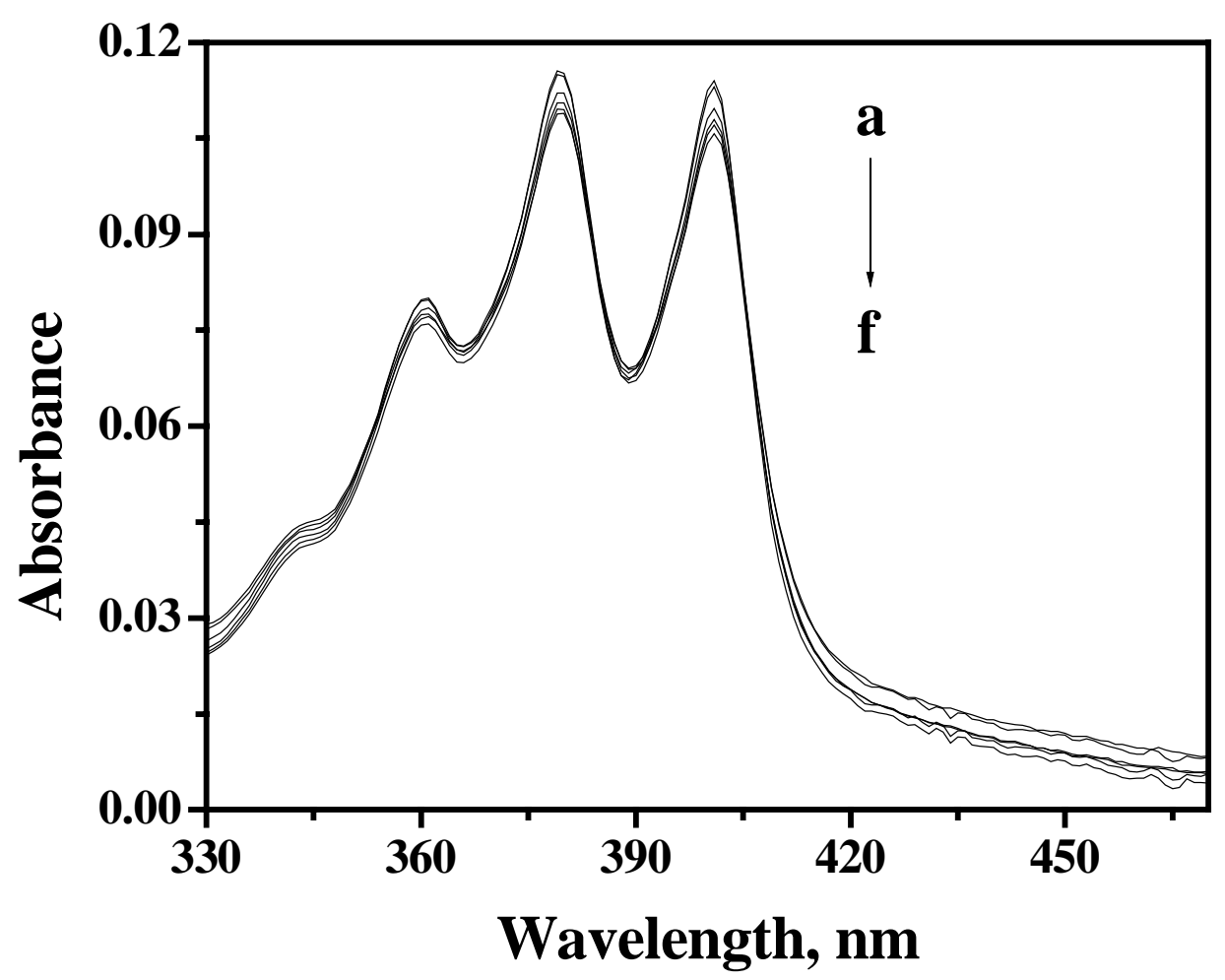

Figure S5. Effect of adenosine-5'-diphosphate (ADP) concentration on the absorption spectrum of $1(11 \mu \mathrm{M})$ in $10 \mathrm{mM}$ phosphate buffer (pH 7.4). [ADP] (a) 0, (b) 0.17, (c) 0.25 , (d) 0.33 , (e) 0.42 and (f) $0.50 \mathrm{mM}$. 


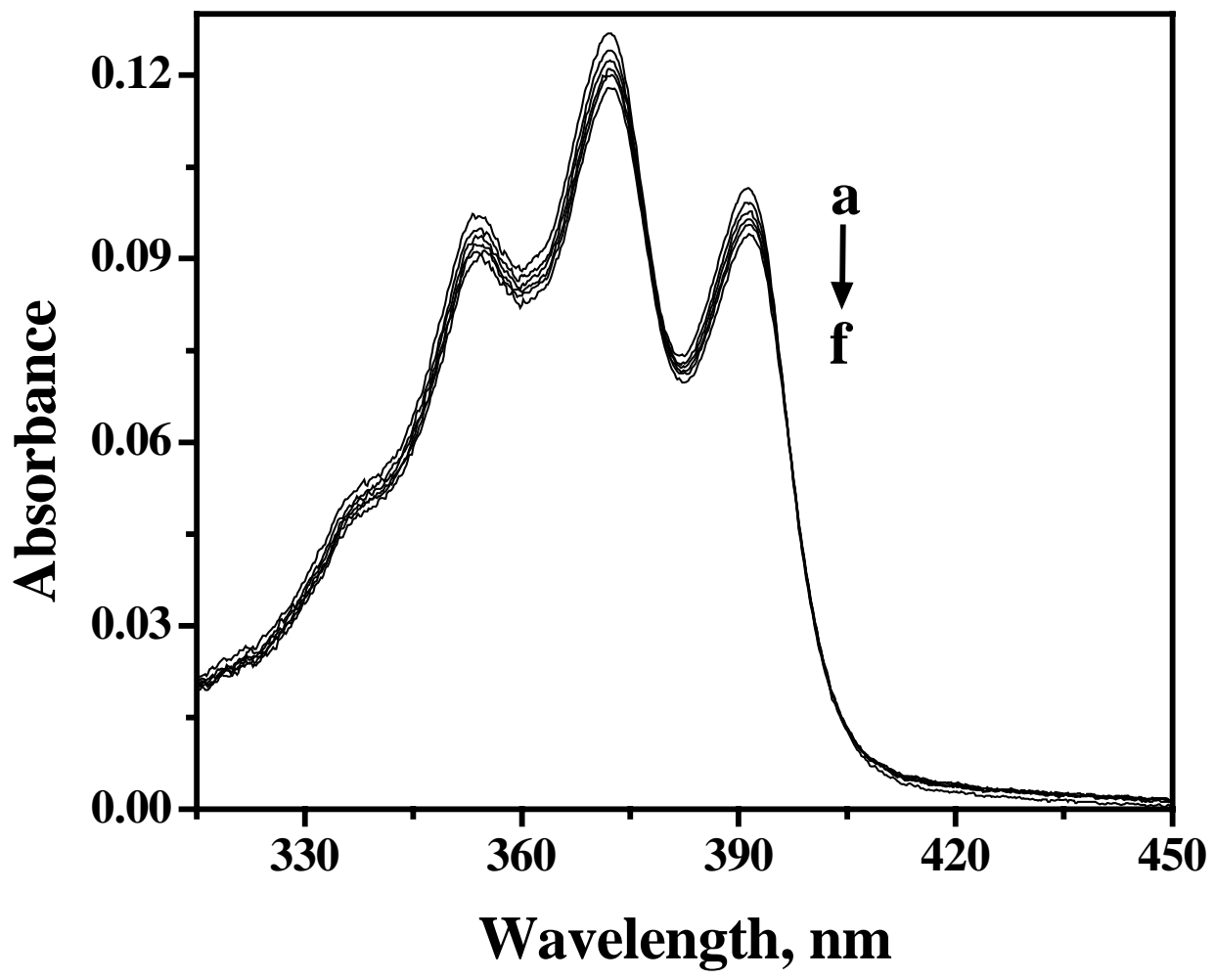

Figure S6. Effect of adenosine-5'-triphosphate (ATP) concentration on the absorption spectrum of $2(15 \mu \mathrm{M})$ in $10 \mathrm{mM}$ phosphate buffer (pH 7.4). [ATP] (a) 0, (b) 0.17, (c) 0.25 , (d) 0.33 , (e) 0.42 and (f) $0.50 \mathrm{mM}$. 


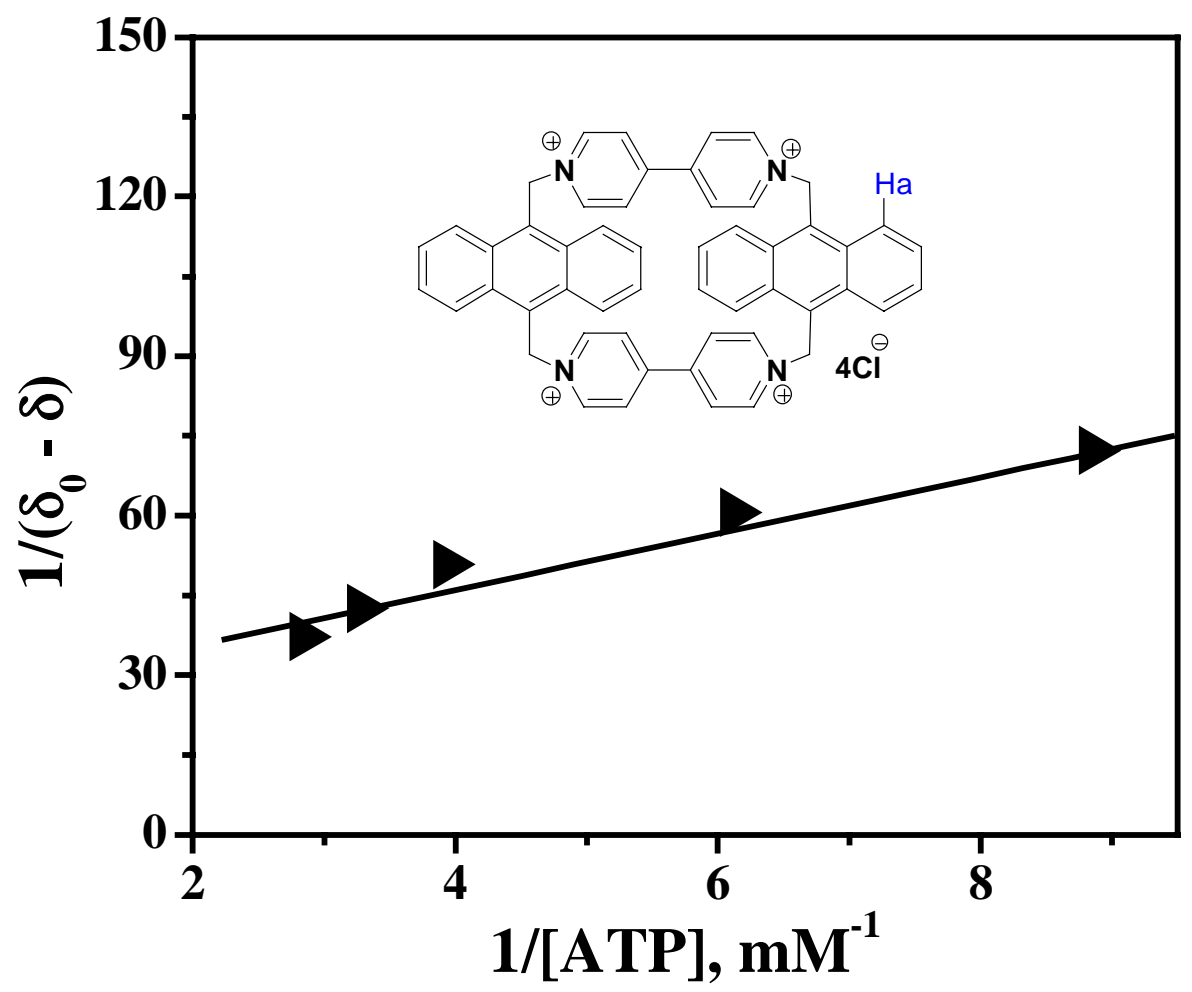

Figure S7. Benesi-Hildebrand plot (NMR titration) for the change in proton chemical shift (' $\mathrm{H}_{\mathrm{a}}$ ' proton) of $\mathbf{1}(4.5 \mathrm{mM})$ in $\mathrm{D}_{2} \mathrm{O}$ with increasing concentrations of ATP. [ATP] (a) 0.06, (b) 0.11, (c) 0.16, (d) 0.25 and (e) $0.35 \mathrm{mM}$. 


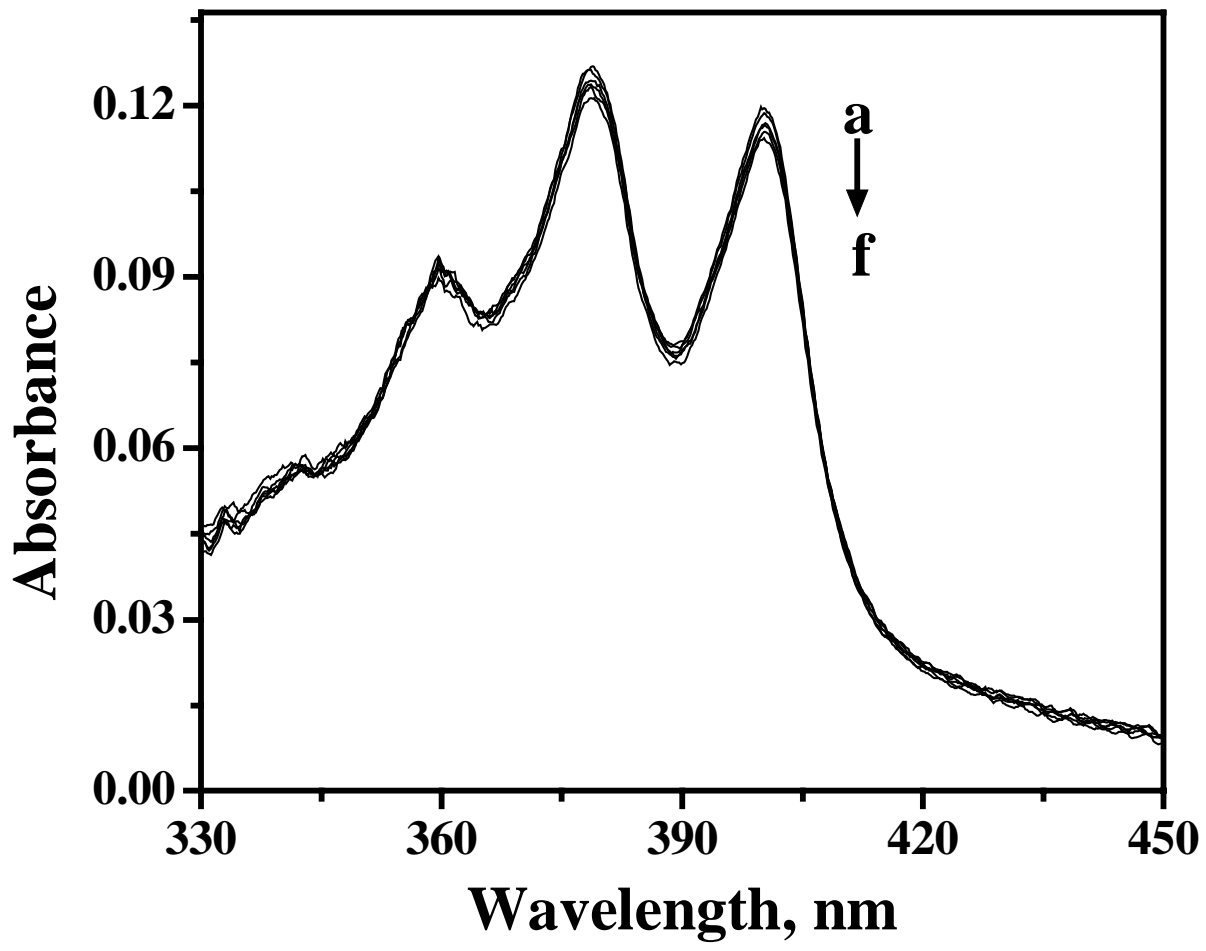

Figure S8. Effect of adenosine-5'-triphosphate (ATP) concentration on the absorption spectrum of $1(11 \mu \mathrm{M})$ in $10 \mathrm{mM}$ phosphate buffer (pH 7.4) containing $500 \mathrm{mM} \mathrm{NaCl}$. [ATP] (a) 0, (b) 0.17, (c) 0.25, (d) 0.33, (e) 0.42 and (f) $0.50 \mathrm{mM}$. 


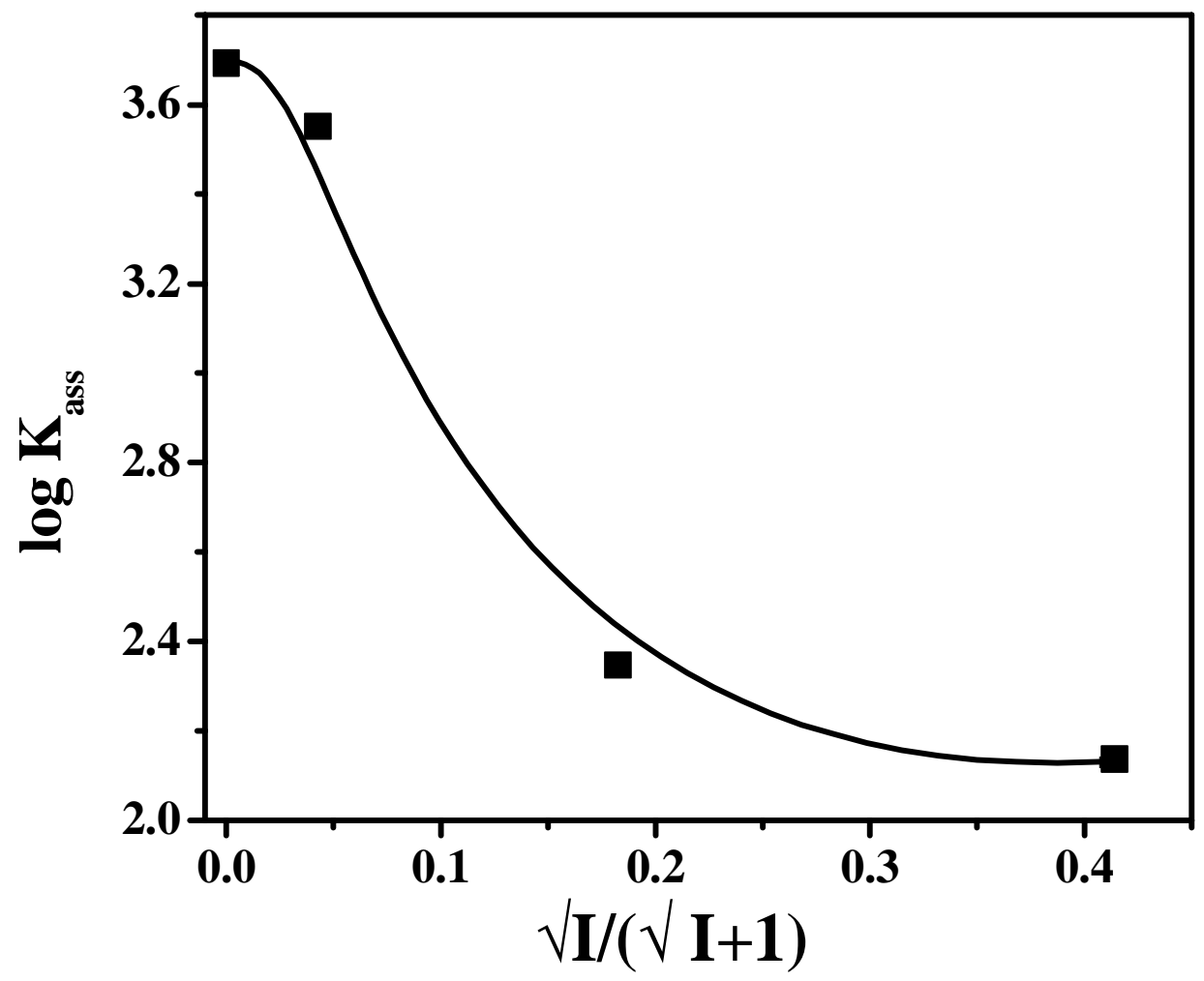

Figure S9. Effect of Debye-Huckel ionic strength function of the medium on the association constants for the complex 1·ATP in $10 \mathrm{mM}$ phosphate buffer $(\mathrm{pH}$ 7.4) under various salt concentrations. [ $\mathrm{NaCl}]$ (a) 0 , (b) 2, (c) 50 and (d) $500 \mathrm{mM}$. 


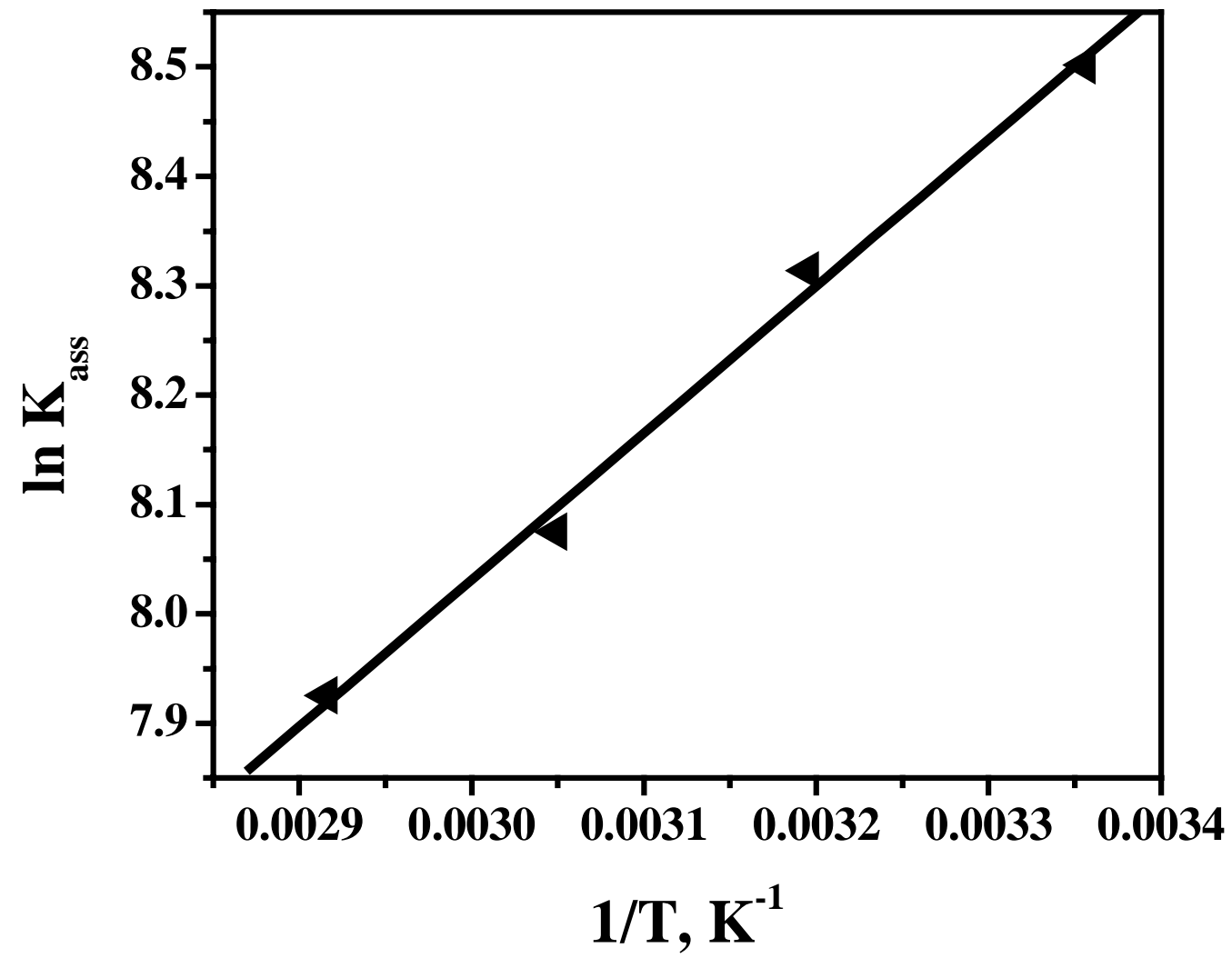

Figure S10. Van't Hoff plot of the association constants $\left(\mathrm{K}_{\mathrm{ass}}\right)$ for the complex $1 \cdot \mathrm{ATP}$ at different temperatures (T), (a) 298, (b) 313, (c) 328 and (d) $343 \mathrm{~K}$. 